\title{
Structural changes and economic growth in China over the past 40 years of reform and opening-up
}

Xiahui Liu

\author{
Institute of Economics Chinese Academy of Social Sciences, Beijing, China
}

\begin{abstract}
Purpose - During the process of reform and opening-up, the structural transformations of the Chinese economy have two significant leaps forward and demonstrate a process of "rural area-industrialization (urban industry and rural industry)-urbanization" development powered by the main engine of economic growth.

Design/methodology/approach - These two leaps forward resulted in transitions of economic structure in China. In the author's view, structural transformations are closely related to China's economic reforms and can be divided into clear phases.

Findings - The structural transformations have two significant leaps forward and demonstrate a process of "rural area-industry (urban industry and rural industry)-urban area development" powered by the main engine of economic growth.

Originality/value - This paper reviews and summarizes the development and structural transformations in China's economy over the last 40 years. The author believes that China's economic miracle is accompanied by dramatic changes in its economic structure, which is particularly characterized by the ongoing process of transition from a traditional agricultural economy into a country with high industrial output, from industrialization into urbanization and from a planned economy into a market economy.
\end{abstract}

Keywords Reform and opening-up, Structural transformations, Economic growth

Paper type Research paper

\section{History and features of structural transformations}

During the process of reform and opening-up, the structural transformations of the Chinese economy have two significant leaps forward and demonstrate a process of "rural areaindustrialization (urban industry and rural industry)-urbanization" development powered by the main engine of economic growth. These two leaps forward resulted in transitions of economic structure in China (Lin et al., 1994). More specifically, in the 1980s, the agricultural sector was the main driver of economic growth, and the economy was dominated by agriculture and rural industries because not only agriculture but also a large number of township enterprises were based in China's rural areas. The second phase started in the 1990s. The rise of the industrial sector in this period was not solely attributed to the development of the urban industry as a large portion of the industry was still based in towns and villages. However, the industrial sector gradually concentrated in urban areas (development zones). After 2003, China's economic growth accelerated and reached a double-digit level as urbanization became the main driver of economic development, and the economy was driven by both urbanization and industrialization. Urbanization mainly refers

(C) Journal of Yangzhou University (Humanities and Social Sciences Edition). Published in China Political Economy. Published by Emerald Publishing Limited. This article is published under the Creative Commons Attribution (CC BY 4.0) licence. Anyone may reproduce, distribute, translate and create derivative works of this article (for both commercial and non-commercial purposes), subject to full attribution to the original publication and authors. The full terms of this licence may be seen at http:// creativecommons.org/licences/by/4.0/legalcode. Originally published in Simplified Chinese in Journal of Yangzhou University (Humanities and Social Sciences Edition).

This article was supported by the innovation project of the Chinese Academy of Social Sciences: “China's Economic Growth and Structural Changes” (2008).

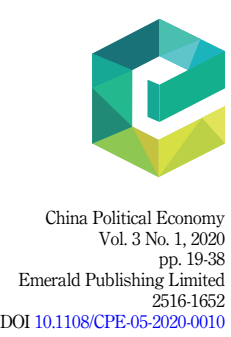


CPE 3,1

to the population shift from rural areas to urban areas, which also indicates the expansion of towns and villages. Such expansion incorporated the majority of industrial sections into urban areas in the process of urban systemization, and there were only small-sized industries in rural areas.

Structural transformations are in close connection with reform and opening-up. These successful reforms in China started in rural areas. Based on voluntary practices in some rural areas, CPC Central Committee released On Several Issues in Strengthening and Improving the Production Responsibility System in Agriculture in September 1980, which allowed peasants to adopt the household responsibility system. As a result, collective-owned township enterprises developed rapidly; and exploration on the path of reform outside the planned economy achieved remarkable progress. These events marked the commencement of reforms in China. We can divide China's reform of the economic system to date into four phases:

(1) Phase 1: the initial phase of economic system reform starting in rural areas (the 3rd Plenary Session of the 11th Central Committee of the Communist Party of China in 1978-the 3rd Plenary Session of the 12th Central Committee of the Communist Party of China in October 1984). The major initiative was the start of the household responsibility system.

(2) Phase 2: fully implementing the entire economic system reform with the focus on urban areas (October 1984-the 14th National Congress of the CPC in 1992). The central aspect of reform was to revive enterprises, and the key was to reform the price system.

(3) Phase 3: initially establishing the socialist economic system (the 14th National Congress of the CPC in 1992-the 16th National Congress of the CPC in 2001). Five comprehensive supporting reforms in the economic system at the macroeconomic level achieved breakthroughs in 1994. From 1997 to 1999, China rolled out reform of the basic economic system, adjusted ownership structure and advanced all-round opening-up. In 2001, China became a member of the World Trade Organization (WTO).

(4) Phase 4 (the 16th National Congress of the CPC in 2001-present): improving the socialist economic system. China has actively been proceeding with reform and constructive efforts for sustainable economic growth as well as social harmony, such as abolishing the agricultural tax, vigorously building the social security system and compressively carrying out the work of energy conservation and emission reduction. Much major work is still underway.

As consistent with those reforms, China's economic growth and structural transformations can also be divided into four phases:

In the first phase (1978-1984), a distinct feature of changes in the industrial structure was the rapid increase in the proportion of the primary industry in the gross domestic product (GDP). In 1984, the primary industry accounted for $32 \%$ of GDP, up $4 \%$ compared with $28 \%$ in 1978. In the same period, the secondary industry decreased by $5 \%$, while the tertiary industry increased by only $1 \%$. These reflect that China's reforms in rural areas and agriculture significantly released productive forces in the agriculture section, boosted the primary industry, and more resources were allocated to the primary industry. In this period, the average annual growth rate (AAGR) of added value at current prices of the primary industry reached $14.5 \%$, exceeding that of the secondary and the tertiary industries, which were 10 and $12.7 \%$, respectively. However, as these changes were compensatory and temporary, the primary industry's contribution to GDP has gradually decreased since 1985. During the first phase, consumer goods industries, such as textiles industry, light industries and other consumer goods industry, made considerable progress and met market demand, 
while the heavy industry was in the process of adjustment, causing a relatively large drop in the proportion of the secondary industry's contribution to GDP.

In the second phase (1985-1992), China's nonagricultural industries developed rapidly. The proportion of the tertiary industry in GDP increased from 28 to $34 \%$, reaching an all-time high. The share of the secondary industry remained at $43 \%$, while that of the primary industry decreased by $6 \%$. Massive transfer of labor force to the tertiary industry was the most prominent feature of resource allocation in this period, which promoted the development of the tertiary industry. Taken as a whole, the development of the tertiary industry also showed features of compensation for development insufficiency and adjustment of industry proportion. In the mid-1980s, the agriculture and consumer goods industries developed, which basically solved the majority of people's problems with food and clothing. At this moment, the contradiction between the pressure of employment and the underdevelopment of the tertiary industry has become increasingly prominent; thus, increasingly more social resources were allocated to the tertiary industry. AAGRs of the added value of the tertiary, the secondary and the primary industries based on current prices were 20,17 and $14.5 \%$, respectively. In this period, the number of employed people in the tertiary industry increased by $34 \mathrm{~m}$, while that in the secondary industry increased by only $25 \mathrm{~m}$. Also, the total number of people working in the tertiary industry surpassed that in the secondary industry in 1994.

In the third phase (1993-2001), China's economy was dominated by the heavy and chemical industries. This period is characterized by the strengthening construction of infrastructure (including energy, transportation and communication facilities), resulting in a rapid increase in the proportion of the secondary industry. During this period, the situation that the growth of heavy industry had always been lower than that of the light industry since the 1980s was changed, and the economic growth was obviously dominated by heavy and chemical industries. Electric power, iron and steel, machinery and equipment, automobile, shipbuilding, chemical, electronics, building materials and other heavy industries became the main driving force for the growth of the national economy. Achievements in energy, transportation and communication infrastructures stimulated demands for products, such as power, transport vehicles, building materials, steels, nonferrous metals, petrochemicals and mechatronics, as well as demands for the construction industry, which boosted the secondary industry. Another feature of this phase was China's growing global economic influence, from 14 coastal cities for opening-up on a trial basis in 1992 to China's accession to WTO in 2001. In undertaking the transfer of international division of labor, China achieved great development in industrialization. With the large-scale transfer of labor force from rural areas, China began to manifest her comparative advantages. In terms of foreign trade, the trade deficit of China in the past turned to the trade surplus in successive years, and the degree of dependence on foreign trade was increasing. The opening-up policy also improved market-oriented reforms. Comprehensive supporting reforms were carried out in the macro-regulation system. The structure of China's economy shifted from a domestic consumption-driven economy to an export-oriented economy. During the 9th Five-Year Plan, the contribution rate of net export to GDP growth was $18.87 \%$. The next export directly drove the second surge of the national economy.

In the fourth phase (the 16th National Congress of the CPC in 2002-present), China's economic growth started to be driven by two "engines," that is, urbanization and industrialization. The urbanization rate has increased rapidly, from $39.09 \%$ in 2002 to $57.35 \%$ in 2016 , and the rate is expected to exceed $60 \%$ by 2020 , which represents entry into a stage of high-level urbanization. The growth of urbanization rate in the past decade largely exceeded those in the 1980s and the 1990s. The double engines accelerated China's economic growth. China experienced a transition from industrialization into urbanization, and its current economic structure transformed from manufacturing-driven to people-oriented. In 2011, the number of urban dwellers in China exceeded those living in rural areas for the first 
CPE 3,1

time, which indicated that China has advanced from a typical agricultural country (the rural population accounted for $82.1 \%$ of the total population in 1978) into a modern urban-based country.

The synchronization of economic structural transformations and reforms and reforms driving structural transformations determined that the transformations of China's economic structure were significantly influenced by the characteristics of China's economic reform, of which the most prominent is that China's economic reform is transforming a planned economy into a socialist market economy step by step, subject to upholding socialist public ownership and paving the way for China's itself at the meantime.

\subsection{Agricultural development}

China's rural reform has brought about the rapid growth of agricultural production and trade of agricultural products. More importantly, it has initiated high growth and economic restructuring in China, and the rapid growth of the economy in the first five years of the 1980s was crucial. After the reform for 40 years, profound changes have taken place in the operation mechanism and management system of China's agriculture and rural economy, which are reflected in the following aspects: firstly, the two-tier management system that integrates unified and separate management on the basis of household contract management has been implemented to stimulate the enthusiasm of farmers' production and management. Secondly, China has developed different economic sectors and operation modes and established a basic economic system with public ownership playing a dominant role and different economic sectors developing side by side. Thirdly, the circulation system of agricultural products has been reformed, and the market for agricultural products has developed greatly. The factor markets based on the land, labor force, capital and technology are taking shape, and the farmers are becoming independent operators from simple producers in the planned economy system. Fourthly, the mandatory production plans have been decreased gradually. More and more economic, legal and information means are used to guide, support, protect and regulate agriculture. In order to better learn about China's rural economic reform and agricultural development, let us have a rough understanding of the operation system and agricultural policies of China before the reform.

\section{Rural economy before the reform}

After the founding of the People's Republic of China, the villages witnessed a transition of the operation and management system from mutual-aid groups, cooperatives, people's communes to "the three-level system of ownership with the production team as the foundation" before 1979. This system has five essential characteristics. Firstly, all means of production were in the ownership of communes, production brigades or production teams. Secondly, the highly centralized collective and unified management system and labor management system were implemented, and all rural labor forces were under centralized and unified management. Thirdly, a simple planned management system was implemented. In terms of production, the national mandatory plan was implemented in the production teams at all levels. (In some places, what to be sowed, how much to be sowed and when to be sowed had to be instructed by the higher authorities.) The main tasks of the cadres at all levels were to fulfill the plan and urge sowing and reaping (the county played the greatest role in implementing the planting plan, so the head of a county became the leader of the production team.) In terms of product circulation, it was completely a purchase and marketing system under state monopoly. Almost all agricultural, sideline, forestry and livestock products were purchased and sold by the state-owned departments according to the mandatory plan. Fourthly, the single operation was dominant in the planting industry. "Taking grain 
production as the top priority" was the basic principle of agriculture, and "food self-supply" was even required in the forest and pastoral areas. In most places, the grain was sown through forest and grass destruction and land clearance. Fifthly, an excessive equalization system was implemented. The work point system was adopted for distribution, and basal rations were equally distributed per capita. The state used administrative means to change the national income earned from agriculture and villages into industrial and urban distribution. It was estimated that from 1950 to 1990, the price scissors between industrial and agricultural products in China were CNY 1,003.9bn, and the agricultural tax was CNY $135.9 b n$. Except CNY 549.7bn for national agricultural investment, the fund for agriculture, and price subsidy, agriculture funded CNY $545.1 b n$ to industry.

Before the reform, the basic rural organization was rural people's commune system, which consisted of commune units, production brigades, production teams and farmers. Political, administrative, social, economic and military functions were all concentrated in the people's commune. The state controlled the production and distribution of agricultural products through the commune system and assigned farming indexes and national production indexes to the production teams. In the people's commune system, the production team was a basic production unit, which was composed of 20-30 farmers on average. The production team committee organized the labor force to engage in production and complete the production plan. The production results were distributed among the members according to their work points after the quotas for purchase under state monopoly were met, and the compensation of the collective production costs was finalized. Individual farmers were only allowed to cultivate their private plots (occupying about $5-7 \%$ of the collective arable lands) and engage in household sideline production in their spare time.

In China, grain crops, including rice, wheat, corn and soybean were bulk agriculture products of staple foods, and oil crops and cotton were also considered as important products to meet the basic needs. To maintain a self-supply of major agricultural products was the top priority among the Chinese agricultural policies. Therefore, the state firmly controlled the production and distribution of grain, oil and cotton. It sold the purchased agricultural products to urban residents at relatively low fixed prices. Dated back to 1953, the purchase system under state monopoly included quota purchase and above-quota purchase. For grain and oil, their prices would vary as purchase types were different. In the people's commune system, for those production teams whose grain yield turned out to be a surplus (If the grain yield of a production team were greater than its total consumption in 1955, including food for commune members and feedstuff for animals, then the production team would be deemed to have a surplus.), the state would purchase a certain proportion of the balance between the actual yield and the planned yield. Meanwhile, the state was obliged to purchase excessive agricultural products from farmers. Before 1965, the price of the products for the above-quota purchase was the same as the price of quota purchase. In 1966, the state issued an incentive system to encourage the production teams to increase the amount of above-quota purchase and offer a high price for the above-quota purchase $(50 \%$ of the above-quota purchase was paid with sugar, vegetable oil and industrial products of the same values. The remaining $50 \%$ was paid with a price, which was 30-50\% higher than the quota purchase price). After the price was raised in 1966, the purchase price of grain remained unchanged from 1966 to 1978. (Exceptionally, the price of soybean was increased by $9 \%$ in 1971 and $23.4 \%$ in 1978.) In 1978, the cost of grain production exceeded $7 \%$ of its purchase price.

This system has the following obvious disadvantages. Firstly, producers were isolated from means of production. Farm households were not recognized as the basic unit of production. All the basic means of production were owned by the collective, which made farmers simply become work point earners who lacked initiative and enthusiasm, and thus, the production efficiency could not be improved. Secondly, the labor achievements of the producers were separated from economic benefits. Income distribution was averaged, and the 
CPE 3,1

operation achievements of the collective were disconnected from the incomes of the farmers, which would make the farmers feel that collective labor was not cost-effective. Thirdly, management and administrative rights were unlinked with initiatives. Nominally, communes, production brigades and production teams had management and administrative rights. However, they had to follow the mandatory plan and unified commands from the higher authorities on what to operate, how to manage, how to distribute the income, how to sell products and how to supply means of production. Fourthly, farmers were limited to the arable lands. They were confined to their limited arable lands by the policies of taking grain as the key link and carrying out a single operation, which curbed the overall development of rural economy and generated low labor productivity and income. Fifthly, urban and rural barriers, as well as urban emphasis (preference) policies, were implemented. Farmers could only live in the rural areas all their lives and were bound permanently by the rigid division of labor and the place of birth. This policy almost became an irrational and inexorable law. It cut off the rational flow of production factors between urban and rural areas, which was an important cause for the division of urban and rural areas and the huge differences in the development of advanced urban areas and underdeveloped rural areas. This system seriously restricted the growth of rural productivity.

\subsection{Rural economic reform and agricultural development}

China has initiated the rural reform since 1979. With the rapid adoption of the household responsibility system (household contract responsibility system with remuneration linked to output), the market-oriented reform was rolled out. Efforts on reforming the agricultural byproduct pricing system, adjusting the industrial structure in rural areas and the development of township enterprises comprehensively boosted the agricultural sector. Agricultural policy changes generally fell into the following categories: agricultural organizations and production policies, policies of purchase of agricultural products under state monopoly and product pricing, as well as trade policies for agricultural products (Table 1).

The rural economic reform can be divided into four phases:

Phase 1: From 1979 to 1984, featured by the farm household being confirmed as a business entity and the hyper-growth of agriculture. The reform focused on rebuilding and restructuring the rural economy to improve agricultural productivity. The implementation of the household responsibility system directly linked farm households' economic interests with business performance, and $99.1 \%$ brigades in people's communes adopted the system of fixing farm output per household between 1979 and 1984. The implementation of the household-based contract system marked the dissolution of the people's commune, a structure with a "three-level system of ownership with the production team as its basis." Farm households became the fundamental units in agricultural production and operation as well as the micro-foundations in the rural economy.

In order to bring the prices of agricultural products produced by farmers back to a reasonable level, the purchase prices of 18 primary agricultural by-products were substantially increased in 1979, with an average increase of $24.8 \%$. Furthermore, there was a gradual reduction in the scope and amount of distribution and purchase of agricultural products under state monopoly. At the end of 1984, the 113 categories of such agricultural products were reduced to 38 categories.

The recognition of farm households as business entities and the improvement of business conditions for agricultural products effectively increased farmers' long-suppressed motivation for increasing production. From 1979 to 1984, the value of China's agricultural output grew at an average rate of $7.3 \%$; the grain output rose from 300 to $400 \mathrm{~m}$ tons, an annual average growth rate of $6.2 \%$; cotton and oil crops experienced a high average annual output increase of 19.3 and $14.7 \%$, respectively. The annual average growth rate of farmer's 


\begin{tabular}{|c|c|c|c|}
\hline Category & Commune system & Household responsibility system & \\
\hline $\begin{array}{l}\text { 1. Production unit } \\
\text { 2. Goals }\end{array}$ & $\begin{array}{l}\text { Production team } \\
\text { (1) Meeting production } \\
\text { quotas } \\
\text { (2) Maintaining a stable } \\
\text { government }\end{array}$ & $\begin{array}{l}\text { Household } \\
\text { (1) Meeting quotas for purchase under state } \\
\text { monopoly } \\
\text { (2) Maximizing profits after meeting quotas }\end{array}$ & $\begin{array}{l}\text { economic } \\
\text { growth in China }\end{array}$ \\
\hline $\begin{array}{l}\text { 3. Economic } \\
\text { decisions }\end{array}$ & \multirow{2}{*}{$\begin{array}{l}\text { Planned by government } \\
\text { Work-based distribution (i.e. } \\
\text { work point system) }\end{array}$} & \multirow{2}{*}{$\begin{array}{l}\text { Meeting quotas, product mix determined by the objective } \\
\text { of profit maximization } \\
\text { Based on the value of production results }\end{array}$} & \\
\hline $\begin{array}{l}\text { - What and how } \\
\text { to produce } \\
\text { - Income } \\
\text { distribution }\end{array}$ & & & \\
\hline 4. Land use & Controlled by the government & Limited right for a family to transfer the right to use land & \\
\hline 5. Workforce & $\begin{array}{l}\text { Workforce migration restricted } \\
\text { by the government }\end{array}$ & $\begin{array}{l}\text { Families are allowed to allocate their labor resources. They } \\
\text { are free to choose when and where they work, but their } \\
\text { moving to cities is restricted }\end{array}$ & \\
\hline 6. Capital & $\begin{array}{l}\text { Capital flow controlled by the } \\
\text { government }\end{array}$ & $\begin{array}{l}\text { Families have the right to make their own investment } \\
\text { decisions, such as purchasing tractors and durable goods, } \\
\text { building houses and investing in rural industries }\end{array}$ & $\begin{array}{r}\text { Table } 1 . \\
\text { Comparison between }\end{array}$ \\
\hline 7. Specialization & $\begin{array}{l}\text { Self-sufficiency highlighted by } \\
\text { national plans }\end{array}$ & $\begin{array}{l}\text { Partial specialization, the principles of comparative } \\
\text { advantage available }\end{array}$ & $\begin{array}{l}\text { the household } \\
\text { responsibility system }\end{array}$ \\
\hline 8. Market & Market places were shut down & $\begin{array}{l}\text { Market places are allowed to open. The government is the } \\
\text { largest buyer of grains and vegetable oils }\end{array}$ & $\begin{array}{r}\text { and the commune } \\
\text { system }\end{array}$ \\
\hline
\end{tabular}

income reached $13.4 \%$. The urban-rural income ratio was reduced from $2.1: 1$ to $1.7: 1$; the ratio of urban-rural consumption expenditure was reduced from 2.8:1 to 2.3:1.

Three major measures were taken in this phase. Firstly, on the premise of adhering to the collective ownership of major means of production, such as land, the management right was separated from the ownership of land, that is, the nationwide introduction of the household responsibility system. Secondly, abolishing the commune system as it was not suitable for the level of rural productive forces and resuming the separation between political organizations and economic organizations in rural areas. Thirdly, reducing the amount of expropriated and purchased grains and importing more grains to enable the farmers to rehabilitate, while continuing to increase the purchase prices of agricultural by-products substantially and maintaining the stable prices of major means of production.

Phase 2: From 1985 to 1998, featured by the reform in the system of agricultural product purchase and marketing under state monopoly and the rapidly evolving industrial structure in rural areas. Several successive years of growth in agricultural output led to structural oversupply in 1982 (primarily poor demands in some local areas). The fiscal subsidies for bulk agricultural commodities, such as grains and oilseeds, were second only to those subsidies making up for state-own industrial enterprises' losses, which imposed a burden on the government. Therefore, the government decided to abolish the system of agricultural product purchase and marketing under state monopoly and implement a "double-track pricing system" (contract ordering and market purchase) on bulk agricultural commodities of grains and oils. For other agricultural products, deregulation was enacted thoroughly, and their prices would be determined by the market.

In light of the result, the removal of restrictions in the market for other agricultural products achieved remarkable success. For instance, the outputs of fruits and aquatic products showed a trend of sustainable growth. However, the reform of the double-track pricing system on bulk agricultural commodities did not achieve the expected outcomes as 
CPE

3,1

this reform merely focused on the purchase system, but failed to make changes in the marketing system. Inversion occurred in both the prices and amounts of purchase and marketing, which led to more rapidly increasing subsidies compared with the subsidies before 1984. In order to ease the government's fiscal burden, along with the reforms in the urban industry after 1984, the Chinese government deregulated the prices of means of agricultural production and gradually eliminated subsidies for agricultural industries. The prices of the means of agricultural production rose sharply, which recorded a rate of $8.9 \%$ in 1984 and $16.2 \%$ in 1988. Since then, the comparative advantage of agricultural production dropped significantly, and the decreasing rate of fertilizers against grains showed a reverse trend. Due to the rapid growth in animal husbandry and fishery, the agricultural output value grew stably at an average annual rate of $4.1 \%$ (lower than 7.35 in the previous phase). In this period, China saw the rise of township enterprises. Their output value achieved an average growth rate of around $50 \%$ annually in output, and the share of their output value in the total product of rural sector soared from $20 \%$ to over $50 \%$. Given that the grain and cotton production (accounting for a large portion of farmers' income) experienced ups and downs, the net income per capita for farmers saw its growth rate $11.1 \%$ lower than the last phase, although it maintained the growth at an annual rate of $2-3 \%$.

Phase 3: From 1989 to 1991, featured by adjustments in the national economy and income stagnation faced by farmers. In this period, China took tight measures to deal with the inflationary spiral and resumed central control over the national economy. For instance, the government reiterated the increase of food production through administrative methods in 1989 .

Since the second half of 1988, the government has resolutely made macroeconomic adjustments and economic rebalancing to control the inflation and overheated economy. Against the background of tight macroeconomic policies, the agricultural section was consolidated significantly. Major agricultural products delivered a substantial increase in output, and crop yield hit record highs. However, the purchase prices of major agricultural products, such as grains and cotton, were lower than the market prices, and serious problems were found in local purchases. Therefore, the government began a monopoly on rice in 1988; in 1990, the system of purchasing at contractual prices was replaced by the system of government purchase at fixed prices, and the cotton operations were managed by supply and marketing cooperatives. During this period, the rural reform was mainly characterized by the regional breakthroughs in the grain purchase and marketing system. Since the food production year of 1988, many grain purchase and marketing regions have rolled out the market-oriented reform in grain purchase and marketing system, with measures of order reduction (reducing the number of ordering contracts), decrease in sales (lowering the sales volume of low-cost grains), rise in prices (increasing both the contractual prices and marketing prices under state monopoly) and removal of price restriction (removing restrictions on purchase and marketing prices), and achieved positive results. This reform led to a reform in 1991 - nationwide implementation of the same prices for both purchase and marketing. In the later part of this period, the government also took some measures meaningful for systems, such as the minimum purchase prices for grains, the establishment of standard central and regional grain wholesale markets and grain reserves for specific purposes.

Phase 4: After 1992, featured by establishing the market economy in rural areas. The goal of establishing a socialist market economy was highlighted in both Deng Xiaoping's speech delivered during his South China tour in 1992 and during the 14th National Congress of the Communist Party of China. In this period, the economy gradually adopted the marketeconomy system and experienced rapid growth. A variety of measures were proposed for rural reform. For instance, based on the original management system and ownership system, a basic framework for the land system was proposed for the first time (establishing the 
system of transferring rural land-use rights based on the extension of rural land contracts for another 30 years); operations at an appropriate scale were promoted in coastal areas, and auction of the right to use barren mountains, slopes, valleys and beaches was promoted in Central and Western China; reforms were carried out in township collective enterprises on various property rights including joint-stock system, lease and auction; the development of new countryside; and abolition of the agricultural tax. Based on the grain purchase and marketing system, $98 \%$ of counties (cities) in China have removed the restrictions on grain prices and purchase and marketing by the end of 1993. After years of slow growth, the agricultural sector developed more rapidly in recent years, and farmers' income also increased significantly (Table 2).

Table 2 shows that the gross output value of agriculture, forestry, animal husbandry and fishery increased from 139.7bn yuan in 1978 to 11.20913 trillion yuan in 2016, with an increase of more than 80 times and an average annual growth rate of $11.9 \%$ while the labor force was declining. Table 3 shows the remarkable increase in farmers' income and significant changes in consumption structure.

\section{Industrialization, urbanization and structural adjustment}

Industrialization is the goal of all backward countries, and developing heavy and chemical industries is the must-choose method for any catching-up country. The history of economic development of developed capitalist countries such as United Kingdom, France, Germany, United States and Japan shows that it takes a long time for the early extensive economy in the Industrial Revolution to be transformed into an intensive one in the postindustrial age (Chenery et al., 1989). Over the past two and more centuries, the former one century is the classical economic growth period, while the latter one century represents the modern economic growth phase that is denoted by the Solow model (Maddison, 1996). During the aforementioned period, significant changes also happened to the economic growth pattern of developed countries: first, the economic growth drivers are manifested by the transformation of "factor accumulation-intensive management-knowledge innovation." Second, the leading industry has experienced the evolution from agriculture to industry and finally to service industry. Third, the role of government, adapting to different stages, has transformed from the "direct quantitative intervention" in the factor accumulation phase to the "marketoriented price adjustment" during the intensive growth and then to the "increase of public expense related to population quality" in the innovative growth phase. The economic development of these countries all features the transition from classical growth to modern growth (Zhang and Liu, 2007, pp. 80-95).

\section{Modernization of the production pattern: industrialization}

China has adopted the strategy of balanced development since the reform and opening-up. A balanced structural development rectifies the severely deformed structure caused by the traditional planned economy that features excessive pursuit of heavy industries, starting the second industrialization of China. Throughout the past 30 years of industrialization, the GDP per capita in China was over US\$3,000 in 2008 and exceeded US\$5,000 in 2011, which marks that China has become a middle-income country. As the industrial structure keeps upgrading, it will be ten years before China completes the industrialization.

The main characteristic of industrialization is that with the growth of GDP per capita and the increase in household consumption, the Engel coefficient continues to decline, leading to the continuous decline of the primary industry; industrialization represented by the manufacturing industry begins to develop; and nonagricultural employment becomes the dominant employment method in the society, replacing the traditional employment method in 
CPE
3,1

\section{8}

Table 2.

Gross output value and related indices of agriculture, forestry, animal husbandry and fishery

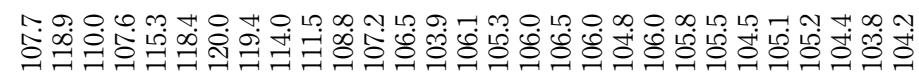

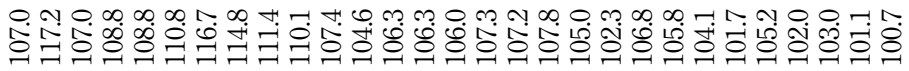

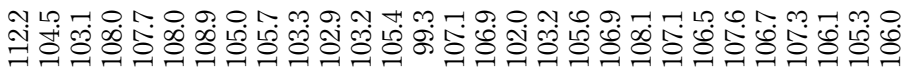

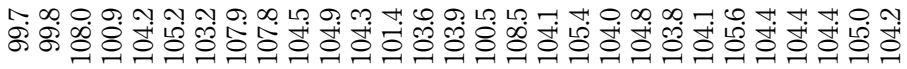

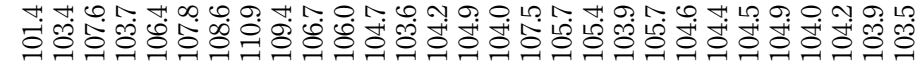

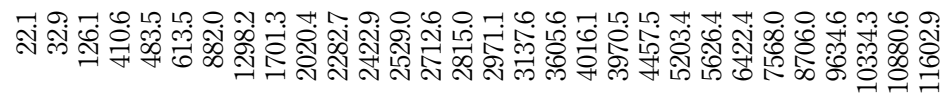

m

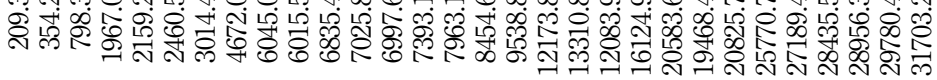

H

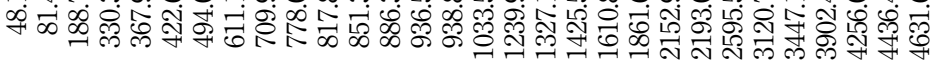

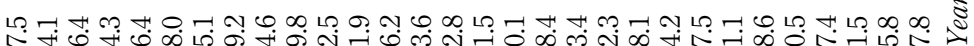

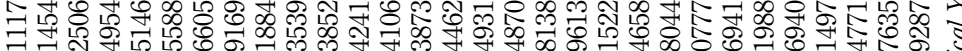
च-

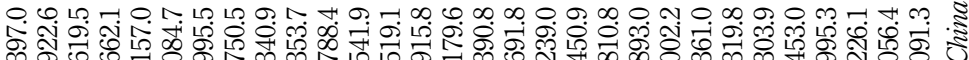

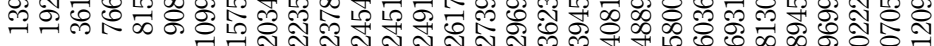




\begin{tabular}{|c|c|c|c|c|c|c|c|}
\hline Items & 1990 & 1995 & 2000 & 2010 & 2011 & 2012 & structure \\
\hline $\begin{array}{l}\text { Number of households surveyed (household) } \\
\text { Number of residents surveyed (person) }\end{array}$ & 66960 & 67340 & 68116 & 68190 & 73630 & 73750 & econom \\
\hline $\begin{array}{l}\text { Permanent residents } \\
\text { Pat }\end{array}$ & 4.80 & 4.48 & 4.20 & 3.95 & 3.90 & 3.88 & gro \\
\hline $\begin{array}{l}\text { Average number of full/semi-labor force per } \\
\text { household }\end{array}$ & 2.92 & 2.88 & 2.76 & 2.85 & 2.78 & 2.76 & \\
\hline $\begin{array}{l}\text { Average number of dependents per labor } \\
\text { force (including the laborer himself or herself) }\end{array}$ & 1.64 & 1.56 & 1.52 & 1.39 & 1.40 & 1.4 & \\
\hline $\begin{array}{l}\text { Per capita annual income (yuan) } \\
\text { Total income }\end{array}$ & 990.38 & 2337.87 & 3146.21 & 8119.51 & 9833.14 & 10990.67 & \\
\hline Income from wages and salaries & 138.80 & 353.70 & 702.30 & 2431.05 & 2963.43 & 3447.46 & \\
\hline Income from household operations & 815.79 & 1877.42 & 2251.28 & 4937.48 & 5939.79 & 6460.97 & \\
\hline Income from properties & 35.79 & 40.98 & 45.04 & 202.25 & 228.57 & 249.05 & \\
\hline Income from transfers & & 65.77 & 147.59 & 548.74 & 701.35 & 833.18 & \\
\hline Cash income & 676.67 & 1595.56 & 2381.60 & 7088.76 & 8638.51 & 9787.19 & \\
\hline Income from wages and salaries & 136.43 & 352.88 & 700.41 & 2427.89 & 2959.74 & 3443.53 & \\
\hline Income from household operations & 481.19 & 1116.73 & 1498.81 & 3955.36 & 4810.37 & 5313.14 & \\
\hline Income from properties & 59.05 & 38.19 & 38.89 & 168.33 & 185.76 & 219.28 & \\
\hline Income from transfers & & 87.76 & 143.49 & 537.18 & 682.64 & 811.25 & \\
\hline Net income & 686.31 & 1577.74 & 2253.42 & 5919.01 & 6977.29 & 7916.58 & \\
\hline Income from wages and salaries & 138.80 & 353.70 & 702.30 & 2431.05 & 2963.43 & 3447.46 & \\
\hline Income from household operations & 518.55 & 1125.79 & 1427.27 & 2832.80 & 3221.98 & 3533.37 & \\
\hline Income from properties & 28.96 & 40.98 & 45.04 & 202.25 & 228.57 & 249.05 & \\
\hline Income from transfers & & 57.27 & 78.81 & 452.92 & 563.32 & 686.7 & \\
\hline $\begin{array}{l}\text { Per capita annual expenditures (yuan) } \\
\text { Total expenditure }\end{array}$ & 903.47 & 2138.33 & 2652.42 & 6991.79 & 8641.63 & 9605.53 & \\
\hline Expenditure for household operations & 241.09 & 621.71 & 654.27 & 1915.62 & 2431.05 & 2626.0 & \\
\hline Purchase of productive fixed assets & 20.29 & 62.33 & 63.90 & 193.26 & 265.75 & 272.61 & \\
\hline Taxes and fees & 38.66 & 88.65 & 95.52 & 8.57 & 11.67 & 10.04 & \\
\hline Expenses on consumption & 584.63 & 1310.36 & 1670.13 & 4381.82 & 5221.13 & 5908.02 & \\
\hline Expenses on properties & 18.80 & 55.28 & 19.74 & 49.25 & 12.27 & 9.86 & \\
\hline Expenses on transfers & & & 148.86 & 443.27 & 699.76 & 778.99 & \\
\hline Cash expenditures & 639.06 & 1545.81 & 2140.37 & 6307.43 & 7984.94 & 8961.85 & \\
\hline Expenditure for household operations & 162.90 & 454.74 & 544.49 & 1757.58 & 2269.19 & 2483.01 & \\
\hline Purchase of productive fixed assets & 20.46 & 62.32 & 63.91 & 193.26 & 265.75 & 272.61 & \\
\hline Taxes and fees & 33.37 & 76.96 & 89.81 & 8.56 & 11.65 & 9.96 & \\
\hline Expenses on consumption & 374.74 & 859.43 & 1284.74 & 3859.33 & 4733.35 & 5414.47 & \\
\hline Expenses on properties & 47.59 & 92.35 & 9.82 & 49.25 & 12.27 & 9.86 & \\
\hline Expenses on transfers & & & 147.60 & 439.45 & 692.73 & 771.94 & \\
\hline \multicolumn{7}{|c|}{$\begin{array}{l}\text { Source(s): China Statistical Yearbook, 2017. The rural household survey was conducted by the } 2012 \text { and prior } \\
\text { Rural Division of the China National Bureau of Statistics }\end{array}$} & $\begin{array}{l}\text { Basic conditions of } \\
\text { rural households }\end{array}$ \\
\hline
\end{tabular}

agricultural society. Since the reform and opening-up policy, the production value and employment quantity ratio of the primary industry has dropped from 28.2 to $70.5-8.6$ and $27.7 \%$ in 2016, respectively (shown in Figure 1). Since the reform and opening-up, the industrialization level has remained at $48 \%$ for a long time. As to the tertiary industry, it takes on an overall upward trend. It accounted for $22 \%$ or so before 1984 ; it experienced a fast growth during the period from 1985 to 1993, reaching around 33\%; after four years' steady development, it increased rapidly during the period from 1997 to 2000, reaching a peak of $41.5 \%$ in 2002 ; over the recent several years, it decreased to some degree and remained $40 \%$, reaching $40.1 \%$ in 2007 and increasing to $51.6 \%$ in 2016. From the perspective of the contribution to economic growth, in 2016, the agricultural contribution to China's economic growth only accounted for $4.3 \%$, the industrial contribution reached $38.2 \%$ and the service 


\section{CPE 3,1}

Figure 1. Changes in the composition of GDP of China $(\%)$
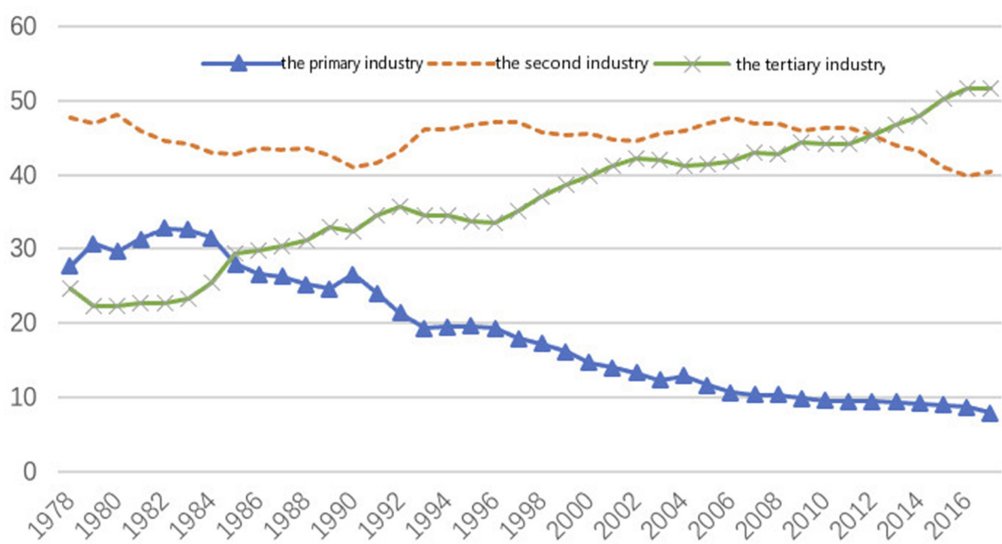

Source(s): China Statistical Yearbook, 2017

industry reached $57.5 \%$. China's industrialization is not only reflected in the contribution to economic growth but also manifested in its great production scale. For instance, the output of steel, coal, cement, chemical fertilizer, chemical fiber, cotton and durable consumer goods ranked the first in the world; the electric energy production ranked the second; and crude oil ranked the sixth in the world. In recent years, high-tech industries in China, such as electronics, have been developed rapidly, and many individual production capacities are also among the highest in the world.

While the Chinese industry develops, agricultural employment declines rapidly, and nonagricultural employment evolves fast, reaching $72.3 \%$ in 2016 . Hence, China has been rendered as an industrialized country dominated by nonagricultural employment. So far, the Chinese economy evolution stage is "secondary, tertiary and primary," supported by the shrinkage of agriculture, the stabilization of industrialization and the enhancement of the tertiary industry. The characteristic of China's economic development is that the industrial sector has always been in a strong position. The secondary industry, especially the manufacturing industry, has always sustained a development of high speed, leading the economic growth. As the contribution of the tertiary industry goes up continuously, by the new era, it has gradually approached that of the industry sector, which manifests that the rapid urbanization substantially facilitates the development of the tertiary industry and meanwhile brings the Chinese economic structure to a more balanced level. To be more specific, the agricultural employment proportion has descended while the secondary industry employment proportion has been stabilized, which surpassed $25 \%$ in 2006 and has remained $22 \%$ or so from the mid-1980s to the 21 st century. Nonagricultural employment mainly depends on the tertiary industry. In the 1990s, the employment proportion of the tertiary industry has surpassed that of the secondary industry, reaching $32.4 \%$ in 2007. However, in terms of output value percentage and the contribution to economic growth, a significant imbalance in the employment proportion still exists. In 2007, the employed population in agriculture still accounted for the largest percentage, reaching $40.8 \%$. It is not until 2011 that the employed population of the tertiary industry starts to surpass that of agriculture by $1 \%$. Therefore, the population allocation in the future is the key for China to realize modernization.

From the aspect of international comparison (World Bank, 1994, 2003a, b, 2008a, b), China's GDP per capita reached about US\$8,260 in 2016, rendering itself an upper-middleincome country with its economic structure and employment basically aligned with the 
general standard. In terms of industry structure, the output value and employment of China's agriculture just reached the threshold of the middle-income economy level while those of the industry surpassed the upper-middle-income level and those of the service industry were far lower than the standard of upper-middle-income economies. On the whole, China is in a transition from a middle-income country toward an upper-middle-income economy. Its core tasks are still accelerating the transfer of rural labor while proactively developing the service industry so that the service industry can support the process of nonagriculturalization and increasing the output value as well as the employment proportion of the service industry, which is directly related to the Chinese modernization (see Table 4).

According to the international practices, when the GDP per capita reaches US $\$ 1,000$, based on the Kuznets model, the service industry added value should account for $40.7 \%$ of the GDP; yet, according to Chenery's model, it should reach $37.8 \%$, which makes it equal to that of the industry added value. Currently, China's industry structure and employment structure are aligned with the Kuznets model, which is similar to the industrialization features of Japan in the 1960s. This stage features the processing industry centralized by the heavy machinery industry when the huge machinery industries such as automotive and shipbuilding replace the light industry and become the dominant factor of economic growth. Due to the requirement in scalation, the Chinese urbanization has been promoted, which accelerates China's pace in postindustrialization and also gradually consolidates the service industry's function in economic growth.

\section{Modernization of the economic structure: urbanization}

According to worldwide experience, the process of industrialization and urbanization can be divided into two stages. In the first stage, industrialization drives urbanization, which is reflected in the following facts: a large number of surplus rural labor forces enter modern sectors; the all-round development of industries in and around cities promotes the establishment of development zones and industrial parks in cities; the speed of urbanization increases significantly; and the status of farmers has been continuously transformed into urban residents. In the second stage, the growth of industrialization is stable or declining, and the increase of urbanization rate is completely driven by the increase in the proportion of nonagricultural employment driven by tertiarization. Industrialization drives the development of urbanization, and the development of urbanization determines the modernization of a country's economic structure, which is manifested in the allocation of population resources and human development.

The level of urbanization in China can be analyzed according to the table of the proportion and speed of urbanization prepared by the World Bank (Table 5). This table divides all countries in the world into low-income, lower-middle-income, upper-middle-income and highincome countries. It lists the situations in the East Asia and Pacific region and Latin America separately. According to this table, it can be seen that although the level of industrialization in China ranks in the forefront of the world, the level of urbanization in China lags behind relatively, which was $55.6 \%$ in 2015 , higher than that of the middle-income group (50.5\%) but still lower than that of the upper-middle-income group (63.8\%) in that year. This situation is basically consistent with that of the East Asia and Pacific region, which reflects that the East Asian model focuses more on industrialization, and urbanization in this region develops relatively weakly. From the aspect of the density of the population of cities with a population of over $1 m$ in the total population, China reached $24.6 \%$ in 2015 , slightly higher than that of the middle-income group. However, the concentration ratio of the population in the largest city was extremely low, with only $3.1 \%$ in China (2015), far lower than any comparable groups. This situation resulted from China's relatively strict household registration control (especially in large cities), which deviates from the law of urban-scale development and agglomeration. In terms of health conditions, the percentage of urban residents with 
CPE

3,1

32

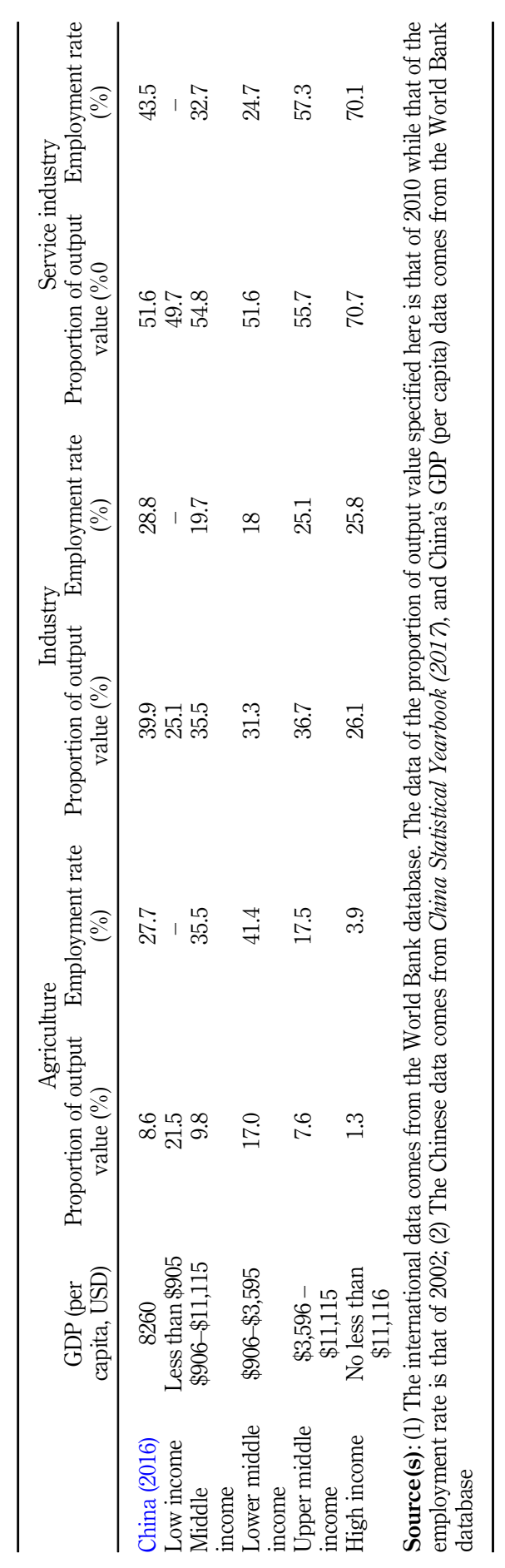

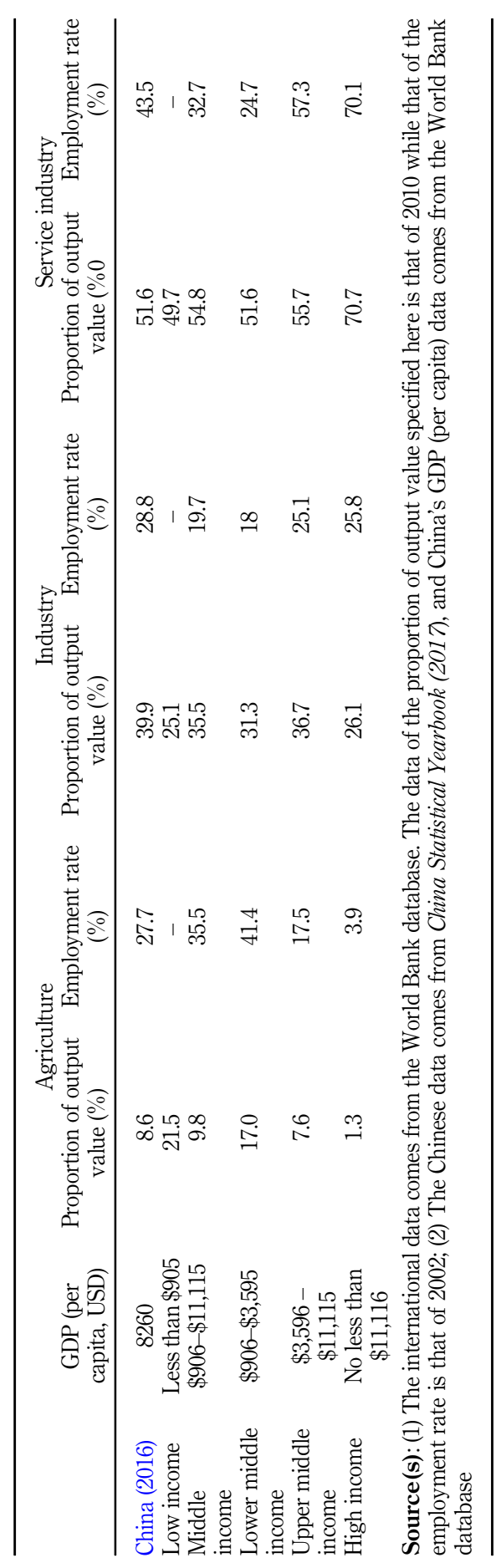

Table 4.

International

comparison of China's production and

employment structure 


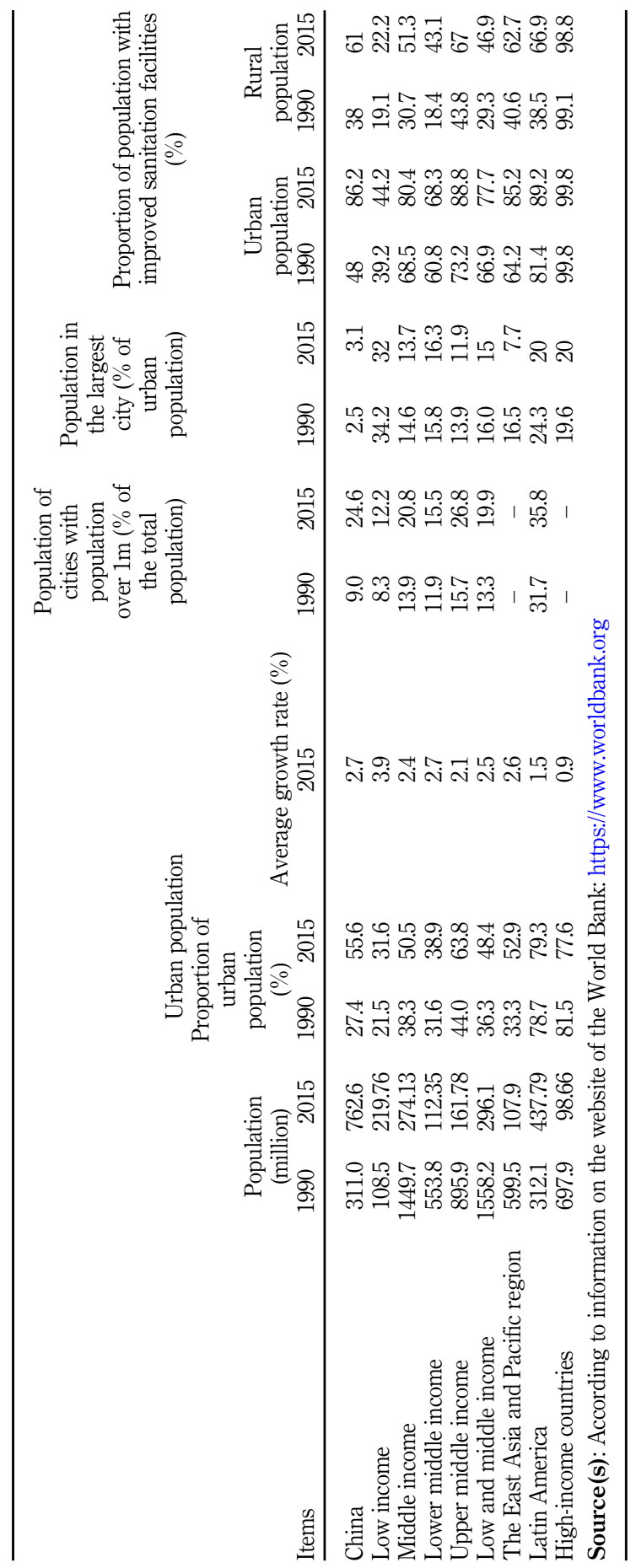

Structural changes, economic growth in China

33

Table 5.

The proportion and speed of urbanization 
CPE 3,1

improved sanitation facilities was $86.2 \%$ in 2015 , higher than the level of $80.4 \%$ in the middleincome group, but slightly lower than that of the upper-middle-income group by $2.6 \%$. However, the proportion of the rural population with improved sanitation facilities is surprisingly higher than that of the middle-income group and close to the level of the uppermiddle-income group. As a whole, the current level of urban development in China is still low and unbalanced. However, fortunately, the growth rate of urbanization in China was higher than that of the middle-income group by $0.3 \%$ (2015). The growth of urbanization is worth looking forward to.

China's urbanization has accelerated since the beginning of the 21st century. The rate of China's urbanization reached $57.35 \%$ in 2016 , and the urbanization target of $60 \%$ of the proportion of the urban population is expected to be achieved by 2020 (Table 6). However, it is worth pointing out that the first process of urbanization is the transformation from industrialization to urbanization and the process of urbanization construction. This process is an accelerated process of urbanization, which is a "construction cycle." This cycle begins under the huge demand for urbanization caused by the accumulation of wealth through industrialization. It promotes the rapid development of real estate, urban construction and taxation, and the economy enters an economic cycle driven by urbanization. China's economy was at this stage from 1997 to 2007 since the adoption of consumption credit, which ignited urbanization. In the future, when the urbanization service industry boosts economic development, the economic growth needs to shift from industrialization to the service industry, and the challenges of the spatial structure transformation of industries, population and land appear.

From the perspective of regions, according to the calculations based on Report on Chinese Industrialization (Huang et al., 2018), industrialization was completed in some regions of China in 2017, and these regions entered the stage of postindustrial society. The first to enter the stage of postindustrial society are some of China's major economic regions, for all of which the urbanization rates reached $75 \%$ (Table 7). Also, it can be further concluded that the urbanization of China in the future will be concentrated in the Pearl River Delta, the Yangtze River Delta and the Circum-Bohai-Sea Region, which is a process of reallocation and optimization of land, resources and population. By 2020, China's industrialization will be basically completed, and the overall urbanization rate will be more than $60 \%$, which is equivalent to the level of urbanization in the period of late industrialization.

\section{Structural optimization and growth mode transformation}

We calculated the contribution of consumption to China's economic growth in each five-year plan period, and the contribution breakdowns of each period, calculated based on prevailing prices, were listed in Table 8. The rate of economic growth and the contribution rate of consumption and investment in the economic growth revealed the big picture. During the 6th and 7 th Five-Year Plans (from 1981 to 1990), the average economic growth rate was $9.74 \%$, in which the contribution rates of consumption were 68.89 and $57.86 \%$, respectively, the contribution rates of investment were 34 and $31 \%$ and the contribution rates of export were

Table 6.

China's urban population and forecast

\begin{tabular}{llccccc}
\hline & \multicolumn{2}{c}{$\begin{array}{c}\text { Proportion of } \\
\text { urban population }\end{array}$} & \multicolumn{2}{c}{$\begin{array}{c}\text { Urban population } \\
\text { (million) }\end{array}$} & \multicolumn{2}{c}{ Average growth rate } \\
Year & 2005 & 2020 & 2005 & 2020 & $2000-2005$ & $2005-2010$ \\
\hline China & 40.4 & 60.3 & 531.8 & 872.6 & 3.2 & 2.7 \\
East Asia & 44.2 & 62 & 921.3 & 1463 & 2.5 & 2.6 \\
World & 48.7 & 59.9 & 3150.5 & 4912.5 & 2.1 & 2
\end{tabular}

Source(s): World Bank (2008a, b), An East Asian Renaissance: Ideas for Economic Growth, CITIC Press 


\begin{tabular}{|c|c|c|c|c|c|c|}
\hline \multicolumn{2}{|l|}{ Stage } & \multirow{2}{*}{$\begin{array}{l}\text { Nationwide } \\
\text { Beijing, Shanghai, Tianjin, } \\
\text { Guangdong, Zhejiang, } \\
\text { Jiangsu and Shandong }\end{array}$} & \multirow{2}{*}{$\begin{array}{l}\begin{array}{l}\text { Four major } \\
\text { economic } \\
\text { areas }\end{array} \\
\begin{array}{l}\text { East coast } \\
\text { China } \\
(98,2009)\end{array}\end{array}$} & \multirow{2}{*}{$\begin{array}{l}\begin{array}{l}\text { Seven major } \\
\text { economic } \\
\text { regions }\end{array} \\
\text { Yangtze river } \\
\text { delta (100) } \\
\text { Pearl river } \\
\text { delta (95) }\end{array}$} & \multirow{2}{*}{$\begin{array}{c}\begin{array}{c}\text { Urbanization } \\
\text { rate }\end{array} \\
75 \%\end{array}$} & $\begin{array}{r}\text { Structural } \\
\text { changes, } \\
\text { economic }\end{array}$ \\
\hline Postindustrialization & $\begin{array}{l}\text { Three cities } \\
\text { and four } \\
\text { provinces }\end{array}$ & & & & & 35 \\
\hline Late industrialization & $\begin{array}{l}\text { The second } \\
\text { half of the } \\
\text { phase: two } \\
\text { provinces } \\
\text { The first half } \\
\text { of the phase: } \\
\text { eight } \\
\text { provinces } \\
\text { and a city }\end{array}$ & $\begin{array}{l}\text { Nationwide }(80,2009) \\
\text { Liaoning and Fujian } \\
\text { Shanxi, Jilin, Inner } \\
\text { Mongolia, Hubei, Hebei, } \\
\text { Heilongjiang, Ningxia, } \\
\text { Shaanxi and Chongqing }\end{array}$ & $\begin{array}{l}\text { Northeast } \\
\text { China (60) }\end{array}$ & $\begin{array}{l}\text { Circum- } \\
\text { Bohai-Sea } \\
\text { Region (90) } \\
\text { Northeast } \\
\text { China (60) }\end{array}$ & $60-75 \%$ & \\
\hline Mid-industrialization & $\begin{array}{l}\text { The second } \\
\text { half of the } \\
\text { phase: } 11 \\
\text { provinces }\end{array}$ & $\begin{array}{l}\text { Qinghai, Hunan, Henan, } \\
\text { Xinjiang, Anhui, Jiangxi, } \\
\text { Sichuan, Gansu, Yunnan, } \\
\text { Guangxi and Hainan }\end{array}$ & $\begin{array}{l}\text { Western } \\
\text { China (40) }\end{array}$ & $\begin{array}{l}\text { Central } \\
\text { region } \\
\text { covering six } \\
\text { provinces } \\
(45) \\
\text { Northwest } \\
\text { China (42) } \\
\text { Southwest } \\
\text { China (40) }\end{array}$ & $50-60 \%$ & \\
\hline $\begin{array}{l}\text { Early phase of } \\
\text { industrialization }\end{array}$ & $\begin{array}{l}\text { The first half } \\
\text { of the phase } \\
\text { The second } \\
\text { half of the } \\
\text { phase } \\
\text { The first half } \\
\text { of the phase }\end{array}$ & Guizhou & & & $30-50 \%$ & \\
\hline Preindustrialization & & Xizang & & & $\begin{array}{c}\text { Lower than } \\
30 \%\end{array}$ & Table 7 \\
\hline $\begin{array}{l}\text { Source(s): Chen Jic } \\
\text { Beijing. The author } n \\
\text { said report }\end{array}$ & $\begin{array}{l}\text { gui et al. (2007 } \\
\text { akes an extrap }\end{array}$ & $\begin{array}{l}\text { Report on Chinese Indust } \\
\text { lation estimation based on }\end{array}$ & $\begin{array}{l}\text { ialization, } \mathrm{Sc} \\
\text { ne rate of cha }\end{array}$ & $\begin{array}{l}\text { ial Sciences } A \\
\text { ge in the data } c\end{array}$ & $\begin{array}{l}\text { ademic Press, } \\
\text { lculated in the }\end{array}$ & $\begin{array}{r}\text { Industrialization } \\
\text { stages of China's main } \\
\text { economic regions }\end{array}$ \\
\hline
\end{tabular}

negative, which reveals that consumption dominated the growth of economy at that period. In the period of the 8th and 9th five-year plans (from 1991 to 2000), the contribution rate of investment rose rapidly during the 8th Five-Year Plan, but the economy remained consumption-led. In 1993, however, the overheating of investment caused a stir. In the 9th Five-Year Plan, investment plus exports overtook consumption, and foreign investment and foreign dependence increased significantly. In order to withstand the 1997 Asian financial crisis, China adopted active fiscal policies and continued to step up the investment contribution. During the 10th Five-Year Plan, the investment contribution rate overtook consumption at $51.1 \%$, becoming the leading factor for economic growth. China has entered an outward-oriented economic pathway since the 9 th Five-Year Plan. Investment and exports have since become the main driving forces for economic growth. In 2006 and 2007, China's economy grew rapidly, as the foreign trade contribution moved to a new high, and the trade dependence continued to go up, to an unreasonable degree for a large economy like China. The mounting trade dependence should be held accountable for the catastrophic scenario in 2009 when the net export contribution reached an awkward record low of $-37.4 \%$, while the investment contribution rate reached an abnormal $87.6 \%$, which boiled down to the low 
CPE 3,1

\section{6}

Table 8.

The breakdown of economic growth contribution during the five-year plan periods after the adoption of reform and opening-up policies consumption contribution in China. Things turned for the better when the contribution of consumption jumped up by $23.4 \%$ from $43.1 \%$ in 2010 to $66.5 \%$ in 2016 .

As the Bureau of Statistics did not publish statistics at constant prices, we instead used the Albert Keidel method to calculate China's GDP and contribution of different factors by expenditure method (calculated at constant prices in 1990). The calculations were basically consistent with our conclusions earlier. We cross-referred and revised the results of years where inconsistency occurred. Consumption contributed the most to GDP during the 1980s when negative net exports and trade deficits have been plaguing China for years. Net exports have increased since the 1990s, and the import and export were obviously powering the economy in many years. Notably, in years with slow economic growth (in 1994, 1995 and 1997), the contributions by investment and net export even exceeded that by consumption.

The economic growth of the 1980s originated from rural reforms. During the period from 1979 to 1985, rural residents' consumption was the dominant force driving economic growth, with the only exception in 1985 when investment exceeded consumption due to the excessive investment in rural housing. Urban reforms in the late 1980s ignited the enthusiasm for consumption in urban residents. Looking at the contribution calculated at constant prices, we found that the economic adjustment in 1989 also originated from the drastic decline in rural household consumption. This once again proved that consumption, especially rural household consumption, was the most important growth contributing and disturbing factor in the 1980s. Starting from 1991, China picked up the pace to open up to the world on the one hand and kicked off a new urban construction cycle on the other hand. This period saw the inclusion of land into tradables in 1992, the housing boom in its early stage, the accumulation of residents' real estate and large-scale urban-bound migration of the rural population. Starting from 1998 until after 2010, stimulated by active fiscal policies and expanding consumption credit, urbanization picked up pace in China, and investment dominated China's economic growth.

From the perspective of international comparisons (Table 9), we found that China's consumption contribution rate in $2016,66.5 \%$, was much lower than that of any comparable group, while the investment contribution rate, as high as $43.1 \%$, was higher than that of any comparable group. In terms of foreign trade, and import and export, China basically fitted into the middle-income group, as it enjoyed thriving foreign trade and showed growing dependence on foreign trade in the first five years after its entry into the WTO. In 2003, China's trade dependence reached $51.9 \%$, exceeding $50 \%$ for the first time, and in 2006 it grew further to $67.0 \%, 28.5 \%$ higher than that in 2001 . Although it started to go down after the financial crisis, China's trade dependence basically stood above $50 \%$. Obviously, a foreign trade dependence of nearly $70 \%$ was too high for a large country like China by the international standard. That was why China suffered terribly in 2009 after the outbreak of the financial crisis. Therefore, it is safe to say that China's demand structure has deviated from

\begin{tabular}{lcccc}
\hline & Investment & Consumption & Net export & GDP growth rate \\
\hline 6th Five-Year Plan (1981-1985) & 33.72 & 68.89 & -2.56 & 10.8 \\
7th Five-Year Plan (1986-1990) & 31.24 & 57.86 & 10.90 & 7.9 \\
8th Five-Year Plan (1991-1995) & 48.81 & 53.05 & -1.20 & 12 \\
9th Five-Year Plan (1996-2000) & 32.15 & 48.79 & 18.87 & 8.3 \\
10th Five-Year Plan (2001-2005) & 41.2 & 51.1 & 7.7 & 9.6 \\
11th Five-Year Plan (2006-2010) & 54.7 & 43.4 & 1.9 & 10.38 \\
12th Five-Year Plan (2011-2015) & 47.2 & 53.18 & -0.38 & 7.84 \\
2016 & 43.1 & 66.5 & -9.6 & 6.7
\end{tabular}

Note(s): The average is calculated at current prices

Source(s): China Statistical Abstract, 2008, and China Statistical Yearbook, 2017 


\begin{tabular}{|c|c|c|c|c|c|c|c|}
\hline & $\begin{array}{l}\text { GDP per } \\
\text { capita (USD) }\end{array}$ & $\begin{array}{c}\text { Total } \\
\text { consumption }\end{array}$ & $\begin{array}{l}\text { Government } \\
\text { consumption }\end{array}$ & $\begin{array}{c}\text { Capital } \\
\text { formation }\end{array}$ & Export & Import & $\begin{array}{l}\text { Structural } \\
\text { changes, }\end{array}$ \\
\hline China (2016) & 8260 & 66.5 & 17.7 & 43.1 & -5.46 & -4.14 & Onom \\
\hline Low income & $\$ 905$ or less & 78 & 11.3 & 28.8 & 24.7 & 28.5 & \\
\hline $\begin{array}{l}\text { Middle } \\
\text { income }\end{array}$ & $\$ 906-\$ 11,115$ & 78.2 & 14.6 & 26.5 & 35.1 & 32.2 & \\
\hline $\begin{array}{l}\text { Lower middle } \\
\text { income }\end{array}$ & $\$ 906-\$ 3,595$ & 78.4 & 14.1 & 26.8 & 33.7 & 31.7 & 37 \\
\hline $\begin{array}{l}\text { Upper middle } \\
\text { income }\end{array}$ & $\begin{array}{l}\$ 3,596- \\
\$ 11,115\end{array}$ & 83.1 & 15.3 & 20.4 & 32.2 & 29.1 & Table 9. \\
\hline High income & $\begin{array}{l}\$ 11,116 \text { or } \\
\text { more }\end{array}$ & - & 18.1 & 20.6 & 25.6 & 26.3 & $\begin{array}{r}\text { International } \\
\text { comparisons of } \\
\text { contribution }\end{array}$ \\
\hline \multicolumn{7}{|c|}{$\begin{array}{l}\text { Source(s): World Bank (2008a, b), An East Asian Renaissance: Ideas for Economic Growth (Chinese } \\
\text { translation), CITIC Press, and China Statistical Yearbook, } 2017\end{array}$} & $\begin{array}{r}\text { breakdown of China's } \\
\text { economic growth) }\end{array}$ \\
\hline
\end{tabular}

normal for a long time. Despite such signs of catching-up as large-scale accumulation and exports, which were significant for a late-comer, China also had its fair share of vulnerability and was vulnerable to external impact.

Compared with the 1990s, in the 21st century, China experienced a slower consumption growth, an expedited investment hike and an obviously faster-growing export. This shift in demand structure was something that East Asia had gone through, except that in China's case, its slowdown in consumption growth under high economic growth was nowhere to be found in any of the comparable group. The economic structure of a country is highly related to the stage of its economic growth. China is now on a concave growth curve. It must strive to make good use of this "catch-up" period it is going through and to make an economic transition. Otherwise, China will fall into a "middle-income trap" as the distortive property of the previous catch-up pathway impedes future-oriented economic adjustments.

Developed countries are gradually transitioning from an intensive growth model to an innovation-driven one, and the modes of resource allocation are shifting to a model of profiting from intellectual innovation, that is, human capital investment, intellectual property, health care, environmental protection and other service sectors are developed, and human has become the main body of economic innovation. The "knowledge rent" obtained through innovation has become the core of making profits and the underpinnings of the innovative growth model of economic factors. China is transitioning from an economic growth model based on factor accumulation to an intensive growth model, with an emphasis on the efficiency of factor allocation. At the same time, due to the large-scale excess of the rural labor force, China will inevitably continue to move in the direction of factor accumulation. At present, the main task of optimizing China's economic structure is to change the mode of economic development, encourage enterprises to make technological innovation and enhance their international competitiveness, adjust the relative price system and accelerate the market-oriented reform of factor prices, so that China can move into a more stable and sustainable development path.

\section{Conclusion}

From the analysis earlier, we came to the following conclusions:

First, since the reform and opening-up 40 years ago, the Chinese economy has undergone drastic structural transformations that enable China's rapid economic growth; second, China's economic growth and structural transformation unfolded phase by phase in sync with the reform and opening-up; third, the Chinese economy has entered a middle-to-high level of development. The Chinese economy may not necessarily have a high level of growth 
CPE 3,1

in the future, but the structural transformation will continue, which requires that China further accelerate the pace of reform and opening-up to keep the economy running at a stable and relatively fast pace.

\section{References}

Chenery, H., et al. (1989), Gongyehua Yu Geguo Jingji Zengzhang Bijiao [Industrialization and Growth: A Comparative Study], SDX Joint Publishing Company and Shanghai People's Publishing House, Shanghai, Chinese edition.

Huang, Q.H., et al. (2018), Zhongguo Gongyehua Jincheng Baogao (1995-2015) [Report on Chinese Industrialization (1995-2015)], Social Sciences Academic Press, Beijing.

Lin, Y.F., Cai, F. and Li, Z. (1994), Zhongguo de qiji: fazhan zhanlue yu jingji gaige [China's Miracle: Development Strategy and Economic Reform], SDX Joint Publishing Company and Shanghai People's Publishing House, Shanghai.

Maddison, A. (1996), Monitoring the World Economy 1820-1992, Revolution Press, Beijing.

World Bank (1994), The East Asian Miracle: Economic Growth and Public Policy, China Financial and Economic Publishing House, Beijing, Chinese edition.

World Bank (2003a), East Asia: Recovery and beyond, China Renmin University Press, Beijing, Chinese edition.

World Bank (2003b), Rethinking the East Asian Miracle, China Renmin University Press, Beijing, Chinese edition.

World Bank (2008a), "World development indicators”, available at: https://www.worldbank.org/ (accessed 22 January 2020).

World Bank (2008b), An East Asian Renaissance: Ideas for Economic Growth, CITIC Press, Beijing, Chinese edition.

Zhang, P. and Liu, X.H. (2007), Zhongguo Jingji Zengzhang Qianyan [The Frontline of China's Economic Growth], Social Sciences Academic Press, Beijing.

\section{Corresponding author}

Xiahui Liu can be contacted at: liu_xh@cass.org.cn

For instructions on how to order reprints of this article, please visit our website:

www.emeraldgrouppublishing.com/licensing/reprints.htm

Or contact us for further details: permissions@emeraldinsight.com 